\title{
OPTIMIZING THE PARAMETERS FOR FRICTION WELDING STAINLESS STEEL TO COPPER PARTS
}

\author{
OPTIMIRANJE PARAMETROV PRI TORNEM VARJENJU \\ NERJAVNEGA JEKLA NA BAKRENE DELE
}

\author{
Mumin Sahin \\ Department of Mechanical Engineering, Trakya University, 22180 Edirne, Turkey \\ mumins@trakya.edu.tr \\ Prejem rokopisa - received: 2015-01-25; sprejem za objavo - accepted for publication: 2015-02-13
}

doi: $10.17222 /$ mit. 2015.023

\begin{abstract}
$\mathrm{St}-\mathrm{Cu}$ (stainless steel and copper) parts were friction welded with the aim to optimize the process parameters in the present study. The joints obtained with various process-parameter combinations were subjected to a tensile test. Empirical relationships were developed to predict the strength of the joints using RSM (the response-surface methodology) and the coherency of the model was tested. The tensile properties, microhardness variations, SEM, the EDS analysis and X-ray diffraction (XRD) analysis of the welded specimens were evaluated. It was found, with an ANOVA analysis, that the friction pressure/friction time relation has the largest influence on the tensile strength of the joints followed by the rotational speed. However, it was also found that the formation of intermetallics at the interface is responsible for a higher hardness and lower tensile strength of the friction-welded stainless steel-copper joints.

Keywords: friction welding, metallurgy, response-surface methodology, tensile strength
\end{abstract}

V predstavljenem delu so bili deli St-Cu (nerjavno jeklo in baker) torno varjeni z namenom optimizacije procesnih parametrov. Spoji, dobljeni z različnimi procesnimi parametri, so bili preizkušeni z nateznim preizkusom. Razvite so bile empirične odvisnosti za napovedovanje trdnosti spojev s pomočjo RSM (Metodologija odgovora površine) in izvršena je bila koherenca modela. Ocenjene so bile natezne lastnosti, spreminjanje mikrotrdote, SEM, EDS analiza in rentgenska difrakcija (XRD) zvarjenih vzorcev. Iz ANOVA analize je bilo ugotovljeno, da ima torni tlak/čas trenja največji vpliv na natezno trdnost spojev, sledi pa mu hitrost vrtenja. Ugotovljeno je bilo, da je večja trdota in manjša natezna trdnost torno varjenih spojev posledica nastanka intermetalne zlitine na stiku nerjavno jeklo-baker.

Ključne besede: torno varjenje, metalurgija, metodologija odgovora površine, natezna trdnost

\section{INTRODUCTION}

Parts made of different materials are known to be cost-effective. The life cycle of the materials, especially in corrosive media, is prolonged. Many ferrous and nonferrous alloys can be friction welded. Friction welding can be used to join metals of widely different thermal and mechanical properties. The combinations that can be friction welded cannot be joined with other welding techniques because of the formation of brittle phases that make the joint poor with respect to mechanical properties. Friction welding prevents distortion of the materials, as heat is not applied.

The welding technology is widely used in manufacturing. The development of new welding methods gained importance along with the developing technology. ${ }^{1-4}$ Welding of different metals and their alloys is a common application in engineering solutions. Fusion welding is almost impossible in such cases due to incompatible physical characteristics and chemical compositions of different metals and alloys. As a result, friction welding was developed. Several researches worked on the heat in friction welding..$^{5-7}$ In friction welding, heat is generated at the interface of the workpieces since mechanical energy is dissipated as heat during the rotation under pressure. Friction welding is a solid-state welding process, using the heat generated through the mechanical friction with a moving workpiece, with an addition of an upsetting pressure to plastically displace the material. Friction welding is generally used to join the parts that are axially symmetrical and have circular cross-sections. However, it can be easily used to join parts without circular cross-sections, with the aid of automation devices and computerized control facilities. ${ }^{8}$ It is an energy saver since heat is not applied.

The friction time and pressure, the upset time and pressure and the speed of rotation are the principal variables in friction welding. ${ }^{9-12}$ There are two types of friction-welding techniques: continuous-drive friction welding and inertia friction welding. Different metals have different hardness values and different melting points. Interface activity during friction welding forms brittle intermetallic phases or eutectics with low melting points. Clean welding surfaces are also of prime importance. ${ }^{13-15}$ In welded St-Cu joints, the joint strength increases with the increasing upset pressure up to the critical value. An increase in the friction time causes a lower strength of a St-Cu joint compared to the $\mathrm{Cu}$ base metal. ${ }^{16}$ A deformation of the material during friction welding is generally due to the diffusion involving a 
migration of lattice defects, which can be influenced by an external electric field. ${ }^{17}$ Sintered powder metallurgical preforms have a low mass, high stiffness and, therefore, their natural frequency is high. Having inherent porosity, they can also be good dampeners besides possessing the latent lubricant. ${ }^{18}$ Maalekian ${ }^{19}$ found that the formation of hard interlayers, such as intermetallic phases, when joining dissimilar materials may cause a joint to become brittle. Further, Sahin et al. ${ }^{20,21}$ showed that the intermetallic phases formed in the interface cause a decrease in the strength of the joints.

However, based on the literature review, Murti and Sundaresan ${ }^{22}$ carried out a study about a parameter optimization using a statistical approach based on factorialexperiment-design friction welding of dissimilar materials. The response-surface methodology (RSM) is a collection of mathematical and statistical techniques that are useful for designing a set of experiments, developing a mathematical model, analyzing the optimum combination of the input parameters and graphically expressing the values. ${ }^{23}$ To obtain the maximum strength, it is essential to have complete control over the relevant process parameters as demonstrated. ${ }^{24}$

Therefore, in this work, an attempt was made to optimize the process parameters of continuous-drive friction welding to achieve the maximum tensile strength of stainless steel-copper parts using the response-surface methodology. Tensile tests were performed on the welded test parts. A microstructure analysis, EDS analysis, XRD analysis and microhardness variations were also carried out on the test parts.

\section{EXPERIMENTAL WORK}

In the experiments, AISI 304 austenitic stainless-steel and copper parts having a diameter of $10 \mathrm{~mm}$ were made using the continuous-drive friction-welding process parameters. The chemical composition and mechanical properties of the stainless-steel and copper parts are presented in Tables $\mathbf{1}$ and 2, respectively, as given in ${ }^{25}$.

Different combinations of the process parameters were used to carry out the trial runs. Process parameters were tested by varying one of the factors while keeping the rest of them at constant values. The working range of each process parameter was determined for a smooth appearance without any observable defects. The selected levels of the process parameters and design matrix with their units and notations are presented in Tables 3 and 4.

However, in order to examine the intermetallic phases formed at the interface of the joints, SEM (scanning electron microscopy) and EDS (energy-dispersive X-ray spectroscopy) were applied to the joints. Examinations were carried out with an SEM-JEOL JSM 5410 LV microscope and in the field of $200 \mathrm{kV}$. In addition, the weld zones of the joints were analyzed in this work since an XRD analysis of the phase constituents in the weld zone is of a great importance.

Then, the strength of the joints was related to the hardness variation within the HAZ. The hardness variations across the welding regions of the joints were measured using a $0.3 \mathrm{~kg}$ load Vickers microhardness test.

\section{RESULTS AND DISCUSSION}

\subsection{Empirical relationships and the optimization}

The responses, the tensile-strength $(T S)$ values of friction-welded joints, are the functions of the frictionwelding parameters such as the friction pressure per second $(F)$, the forging pressure per second $(D)$ and the rotational speed per second $(N)$ and they can be expressed as:

Table 1: Chemical composition of austenitic stainless steel used in the experiment $\mathrm{t}^{25}$

Tabela 1: Kemijska sestava avstenitnega nerjavnega jekla, uporabljenega pri preizkusu ${ }^{25}$

\begin{tabular}{|c|c|c|c|c|c|c|c|c|}
\hline Material & $\% \mathrm{C}$ & $\% \mathrm{P}$ & $\% \mathrm{~S}$ & $\% \mathrm{Mn}$ & $\% \mathrm{Si}$ & $\% \mathrm{Cr}$ & $\% \mathrm{Ni}$ & $\begin{array}{c}\text { Tensile strength } \\
(\mathrm{MPa})\end{array}$ \\
\hline $\begin{array}{c}\text { AISI 304 } \\
\text { (X5CrNi1810) }\end{array}$ & $<0.07$ & $<0.045$ & $<0.030$ & $<2.0$ & $<1.0$ & $17-19$ & $8.5-10.5$ & 825 \\
\hline
\end{tabular}

Table 2: Chemical composition of copper used in the experiment

Tabela 2: Kemijska sestava bakra, uporabljenega pri preizkusu

\begin{tabular}{|c|c|c|c|c|c|c|c|c|c|c|c|c|c|c|c|}
\hline Copper & $\% \mathrm{Sn}$ & $\% \mathrm{~Pb}$ & $\% \mathrm{Zn}$ & $\% \mathrm{P}$ & $\% \mathrm{Mn}$ & $\% \mathrm{Fe}$ & $\% \mathrm{Ni}$ & $\% \mathrm{Si}$ & $\% \mathrm{Mg}$ & $\% \mathrm{Al}$ & $\% \mathrm{Bi}$ & $\% \mathrm{~S}$ & $\% \mathrm{Sb}$ & $\% \mathrm{Cu}$ & $\begin{array}{c}\text { Tensile strength } \\
(\mathrm{MPa})\end{array}$ \\
\hline & 0.00222 & $<0.0020$ & $<0.0010$ & 0.00137 & $<0.0005$ & 0.0381 & $<0.0010$ & 0.00745 & 0.00376 & 0.00500 & $<0.0005$ & 0.00251 & $<0.0020$ & 99.93 & 300 \\
\hline
\end{tabular}

Table 3: Feasible working limits of friction-welding parameters

Tabela 3: Območje delovnih parametrov pri tornem varjenju

\begin{tabular}{|l|c|c|c|c|c|c|}
\hline \multicolumn{1}{|c|}{ Parameter } & \multirow{2}{*}{ Notation } & \multirow{2}{*}{ Unit } & \multicolumn{4}{c|}{ Level } \\
\cline { 4 - 7 } & & & -1.68 & $(-1)$ & $(0)$ & $(+1)$ \\
\hline Friction pressure/Friction time & $F$ & $\mathrm{MPa} / \mathrm{s}$ & 3.78 & 5.82 & 8.82 & 11.82 \\
\hline Upset pressure/Upset time & $D$ & $\mathrm{MPa} / \mathrm{s}$ & 2.96 & 5 & 13.86 \\
\hline Rotational speed/sec & $N$ & $\mathrm{~s}^{-1}$ & 18.46 & 20.5 & 23.5 & 26.5 \\
\hline
\end{tabular}


Table 4: Design matrix and the corresponding output response Tabela 4: Postavljena matrika in ustrezni dobljeni odgovori

\begin{tabular}{|c|c|c|c|c|c|}
\hline \multirow{2}{*}{$\begin{array}{c}\text { Standard } \\
\text { order }\end{array}$} & \multirow{2}{*}{$\begin{array}{c}\text { Run } \\
\text { order }\end{array}$} & \multicolumn{3}{|c|}{ Original value } & Tensile \\
\cline { 3 - 5 } & & $F$ & $D$ & $N$ & $\begin{array}{c}\text { strength } \\
(\text { MPa })\end{array}$ \\
\hline 16 & 1 & 8.82 & 8 & 23.5 & 223 \\
\hline 18 & 2 & 8.82 & 8 & 23.5 & 222 \\
\hline 4 & 3 & 11.82 & 11 & 20.5 & 190 \\
\hline 9 & 4 & 3.78 & 8 & 23.5 & 150 \\
\hline 20 & 5 & 8.82 & 8 & 23.5 & 218 \\
\hline 6 & 6 & 11.82 & 5 & 26.5 & 210 \\
\hline 15 & 7 & 8.82 & 8 & 23.5 & 223 \\
\hline 1 & 8 & 5.82 & 5 & 20.5 & 130 \\
\hline 7 & 9 & 5.82 & 11 & 26.5 & 213 \\
\hline 5 & 10 & 5.82 & 5 & 26.5 & 180 \\
\hline 8 & 11 & 11.82 & 11 & 26.5 & 215 \\
\hline 12 & 12 & 8.82 & 13.04 & 23.5 & 217 \\
\hline 11 & 13 & 8.82 & 2.96 & 23.5 & 160 \\
\hline 10 & 14 & 13.86 & 8 & 23.5 & 216 \\
\hline 3 & 15 & 5.82 & 11 & 20.5 & 150 \\
\hline 19 & 16 & 8.82 & 8 & 23.5 & 222 \\
\hline 17 & 17 & 8.82 & 8 & 23.5 & 219 \\
\hline 13 & 18 & 8.82 & 8 & 18.46 & 200 \\
\hline 14 & 19 & 8.82 & 8 & 28.54 & 215 \\
\hline 2 & 20 & 11.82 & 5 & 20.5 & 195 \\
\hline & & & & & \\
\hline
\end{tabular}

$$
T S=f\{F, D, N\}
$$

The second-order polynomial (regression) equation used to represent the response surface $Y(T S)$ is as follows:

$$
Y=b_{0}+\Sigma b_{\mathrm{i}} x_{\mathrm{i}}+\Sigma b_{\mathrm{ii}} x_{\mathrm{i}}^{2}+\Sigma b_{\mathrm{ij}} x_{\mathrm{i}} x_{\mathrm{j}}
$$

and for three factors, the selected polynomial could be expressed as:

$$
\begin{gathered}
T S=b_{0}+b_{1}(F)+b_{2}(D)+b_{3}(N)+b_{12}(F D)+b_{13}(F N)+ \\
+b_{23}(D N)+b_{11}\left(F^{2}\right)+b_{22}\left(D^{2}\right)+b_{33}\left(N^{2}\right)
\end{gathered}
$$

Regression coefficients are $b_{1}, b_{2}, b_{3}, \ldots b_{44}$ where $b_{0}$ is the average of the responses and they depend on the respective linear, interaction and squared terms of the factors as shown $\mathrm{in}^{26,27}$. The significance of each coefficient was determined with a $t$-test and $p$-values, listed in Table 5.

The value of a coefficient was calculated using the Design-Expert software. The values of the probability $>F$ of less than 0.05 indicate that the model terms are significant. In this case, $F, D, N, F D, F N, D N, F^{2}, D^{2}$ and $N^{2}$ are significant model terms. The values greater than 0.1 point out that the model terms are not significant. The results of multiple linear regression coefficients for the second-order response surface model are given in Table 6.

The final empirical relationship was obtained using only these coefficients, and the developing final empirical relationship for the tensile strength is given below:

$T S=[221.36+18.16 F+10.90 D+13.05 N-6.62 F D-$ $\left.9.12 F N+2.88 D N-14.74 F^{2}-12.80 D^{2}-6.08 N^{2}\right]$

\begin{tabular}{|c|c|c|c|c|c|c|}
\hline & \multirow{2}{*}{$\begin{array}{l}\text { Sum of } \\
\text { squares }\end{array}$} & \multirow[b]{2}{*}{$\mathrm{d} f$} & \multirow{2}{*}{$\begin{array}{c}\text { Mean } \\
\text { square }\end{array}$} & \multirow{2}{*}{$F$-value } & \multirow{2}{*}{$\begin{array}{c}P \text {-value } \\
\text { prob }>F\end{array}$} & \multirow{16}{*}{ 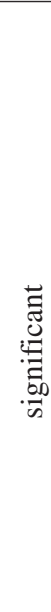 } \\
\hline Source & & & & & & \\
\hline Model & 14726.69 & 9 & 1636.30 & 13.39 & 0.0002 & \\
\hline A-F & 4503.47 & 1 & 4503.47 & 36.85 & 0.0001 & \\
\hline B-D & 1622.62 & 1 & 1622.62 & 13.28 & 0.0045 & \\
\hline $\mathrm{C}-\mathrm{N}$ & 2325.93 & 1 & 2325.93 & 19.03 & 0.0014 & \\
\hline $\mathrm{AB}$ & 351.12 & 1 & 351.12 & 2.87 & 0.1209 & \\
\hline $\mathrm{AC}$ & 666.12 & 1 & 666.12 & 5.45 & 0.0417 & \\
\hline $\mathrm{BC}$ & 66.13 & 1 & 66.13 & 0.54 & 0.4789 & \\
\hline $\mathrm{A}^{\wedge} 2$ & 3132.15 & 1 & 3132.15 & 25.63 & 0.0005 & \\
\hline $\mathrm{B}^{\wedge} 2$ & 2360.38 & 1 & 2360.38 & 19.31 & 0.0013 & \\
\hline $\mathrm{C}^{\wedge} 2$ & 532.80 & 1 & 532.80 & 4.36 & 0.0633 & \\
\hline Residual & 1222.11 & 10 & 122.21 & & & \\
\hline Lack of fit & 1199.28 & 5 & 239.86 & 52.52 & 0.0003 & \\
\hline Pure error & 22.83 & 5 & 4.57 & & & \\
\hline Cor. total & 15948.80 & 19 & & & & \\
\hline Std. dev. & \multicolumn{2}{|c|}{11.05} & \multicolumn{2}{|c|}{$R$-squared } & \multicolumn{2}{|c|}{0.9234} \\
\hline Mean & \multicolumn{2}{|c|}{198.40} & \multicolumn{2}{|c|}{ Adj. $R$-squared } & \multicolumn{2}{|c|}{0.8544} \\
\hline
\end{tabular}

Table 5: ANOVA test results for the response of the tensile strength Tabela 5: Rezultati ANOVA preizkusa za odgovore natezne trdnosti

Table 6: Estimated regression coefficients

Tabela 6: Ocenjeni regresijski koeficienti

\begin{tabular}{|c|c|}
\hline \multirow{2}{*}{ Factor } & $\begin{array}{c}\text { Estimated regression } \\
\text { coefficients }\end{array}$ \\
\cline { 2 - 2 } & Tensile strength $(\mathrm{MPa})$ \\
\hline Intercept & 221.36 \\
\hline$F$-friction force/friction time & 18.16 \\
\hline$D$-upset force/upset time & 10.90 \\
\hline$N$-rotational speed & 13.05 \\
\hline$F D$ & -6.62 \\
\hline$F N$ & -9.12 \\
\hline$D N$ & 2.88 \\
\hline$F^{2}$ & -14.74 \\
\hline$D^{2}$ & -12.80 \\
\hline$N^{2}$ & -6.08 \\
\hline
\end{tabular}

The ANOVA (analysis of variance) technique was used to check the adequacy of the developing empirical relationship. In this investigation, the desired level of confidence was taken to be $95 \%$. The relationship is considered adequate if the calculated $F$-value of the model developed does not go over the standard tabulated $F$-value and the calculated $R$-value of the developed relationship exceeds the standard tabulated $R$-value for a desired level of confidence. It was found that the above model is adequate. In the same way, interactions $F D, F N$, $D N$ had significant effects. A lack of fit was not significant though it was desired. The normal probability plot of the residuals for the tensile strength is shown in Figure 1. It reveals that the residuals are on a straight line, which means that the errors are distributed normally. Each predicted value matches well its experimental value, as shown in Figure 2. The response-surface methodology (RSM) was used to optimize the frictionwelding parameters in this study. The response contours can assist in the prediction of the response for any zone in the experimental field as observed in ${ }^{24,25}$. 


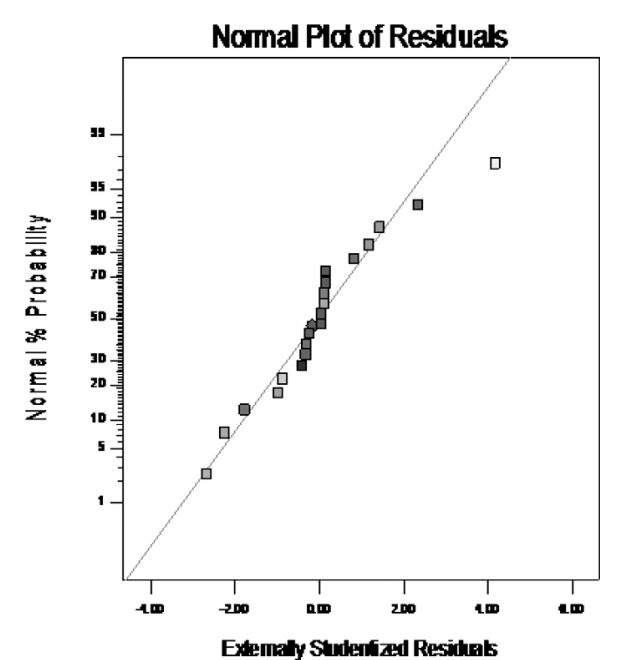

Figure 1: Normal probability plot of residuals Slika 1: Normalna verjetnost izrisa ostankov

The end of the response plot shows the maximum achievable tensile strength. Figures 3 and $\mathbf{4}$ show that the tensile strength increases with the increasing friction pressure/time relation and rotational speed and then it decreases.

The maximum tensile strength of the friction-welded joints was attained under the following welding conditions: a friction pressure/time relation of $8.82 \mathrm{MPa} / \mathrm{s}$ (a friction pressure of $75 \mathrm{MPa}$ and a friction time of $8.5 \mathrm{~s}$ ), an upset pressure/time relation of $8 \mathrm{MPa} / \mathrm{s}$ (an upset pressure of $160 \mathrm{MPa}$ and an upset time of $20 \mathrm{~s}$ ) and a rotational speed of and $23.5 \mathrm{~s}^{-1}$, showing the accuracy of the model.

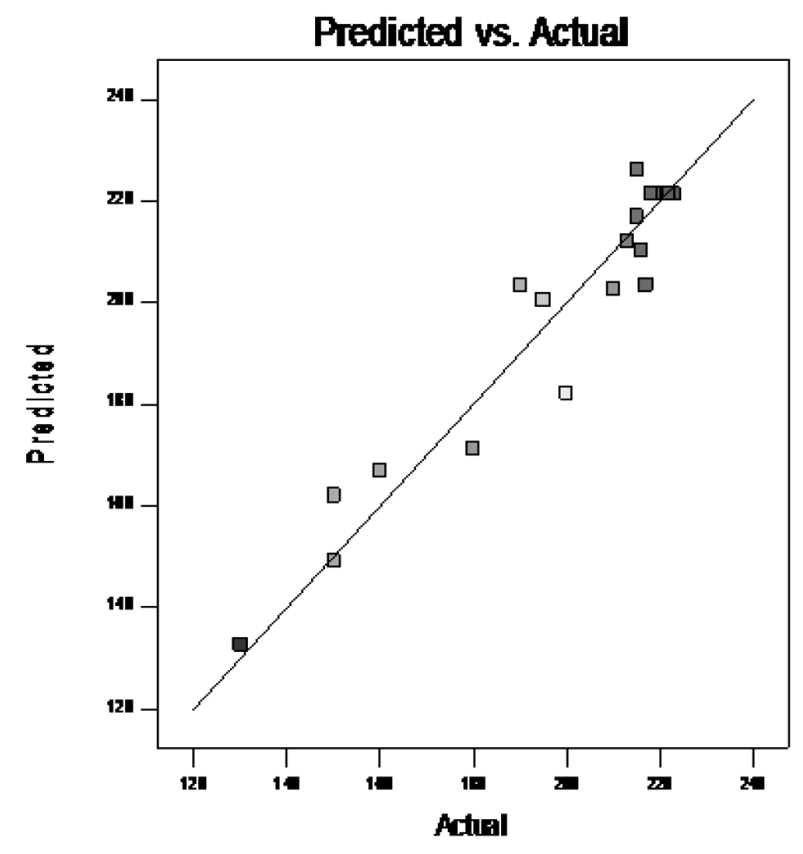

Figure 2: Correlation graph of the response Slika 2: Prikaz korelacije odziva
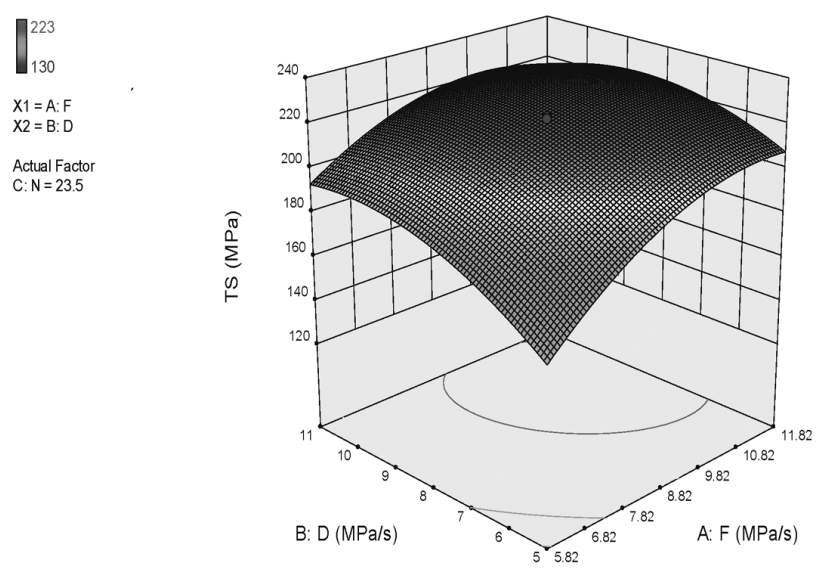

Figure 3: Response plots of the process parameters for the tensile strength

Slika 3: Prikaz odziva procesnih parametrov na natezno trdnost

During the welding processes, the strength of the welds obtained with dissimilar materials strongly depends on the temperature attained by each substrate. Differences in the mechanical and thermophysical properties and behaviour of the substrates at the interface influence the quality of the joints during the welding as reported in ${ }^{20,21}$.

\subsection{Metallurgical analysis}

The macrophotography of the joints is given in Figure 5. There is no evidence of cracking or other defects in the joints. Due to the variations in the strength of the materials, an appreciable variation in the width of the HAZ (heat-affected zone) region is evident from the joints. However, the microstructure of stainless steel is characterized by equiaxed grains, in the austenitic-grain structure being the natural structure of this type of steel at room temperature (Figure 6).

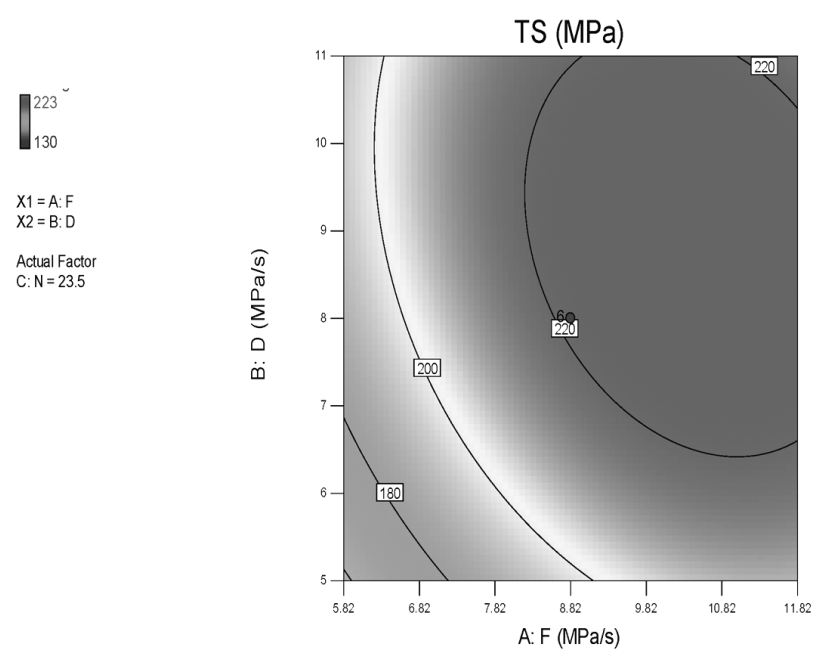

Figure 4: Contour plots of the process parameters for the tensile strength

Slika 4: Prikaz obrisov procesnih parametrov na natezno trdnost 


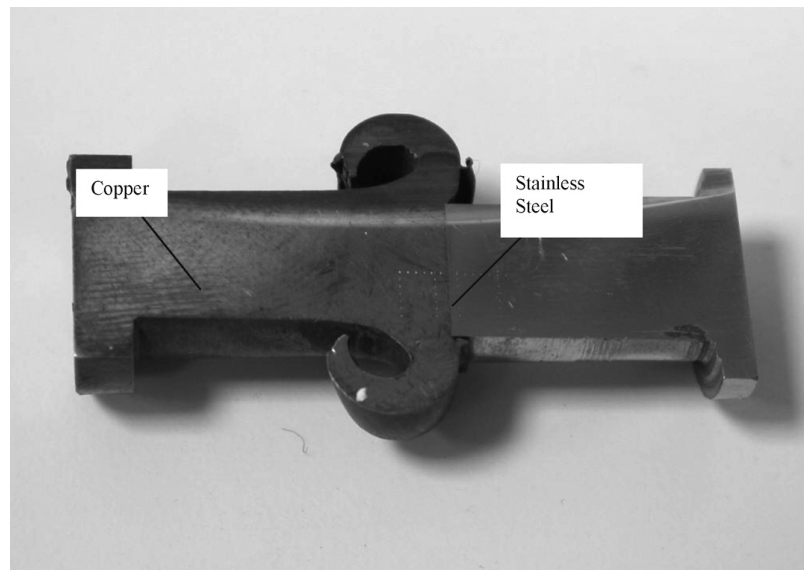

Figure 5: Macrophotography of a joint

Slika 5: Makroposnetek spoja

However, copper is formed of eutectic particles, having dark points indicating that it is a mixture of pure copper and cuprous oxide, dispersed in the ground copper (Figure 7). The effect of melting was minimal at the interface because the heat-affected zone (HAZ) was small (Figure 8).

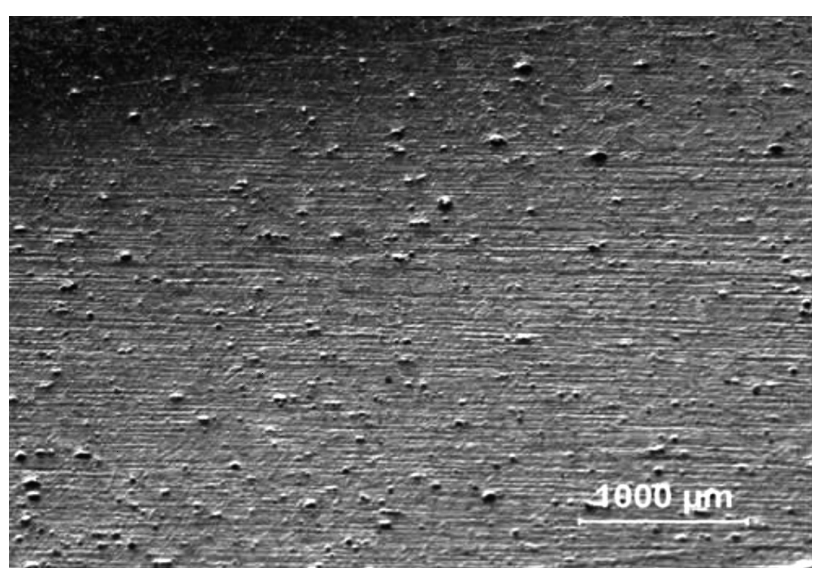

Figure 6: Microstructure of stainless steel Slika 6: Mikrostruktura nerjavnega jekla

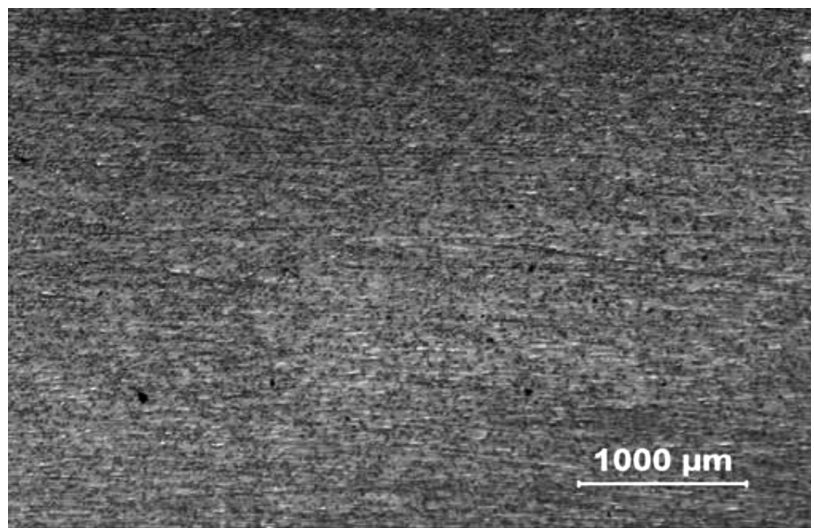

Figure 7: Microstructure of copper

Slika 7: Mikrostruktura bakra

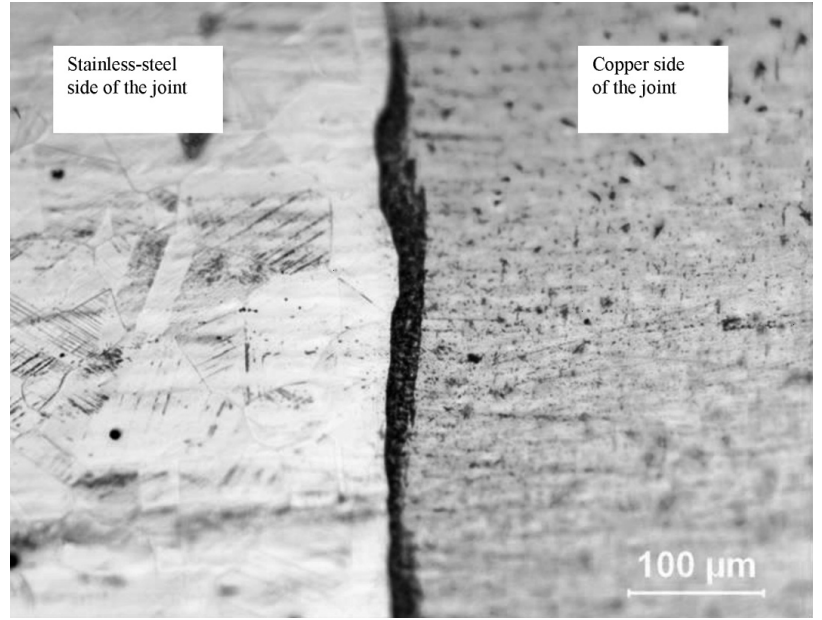

Figure 8: Image of the interface of a joint Slika 8: Posnetek stika v spoju

It is also observed that the joints have larger deformations on the $\mathrm{Cu}$ side compared to the steel side (Figure 5). Welding flashes occur on the copper side of the interface because the melting temperature of copper is lower than the melting temperature of steel. However, stainless steel does not undergo an extensive deformation while copper undergoes an extensive melting because of the high generated and concentrated frictional heat.

Since copper has a higher thermal conductivity than steel, the heat-affected zone on the copper side is wider
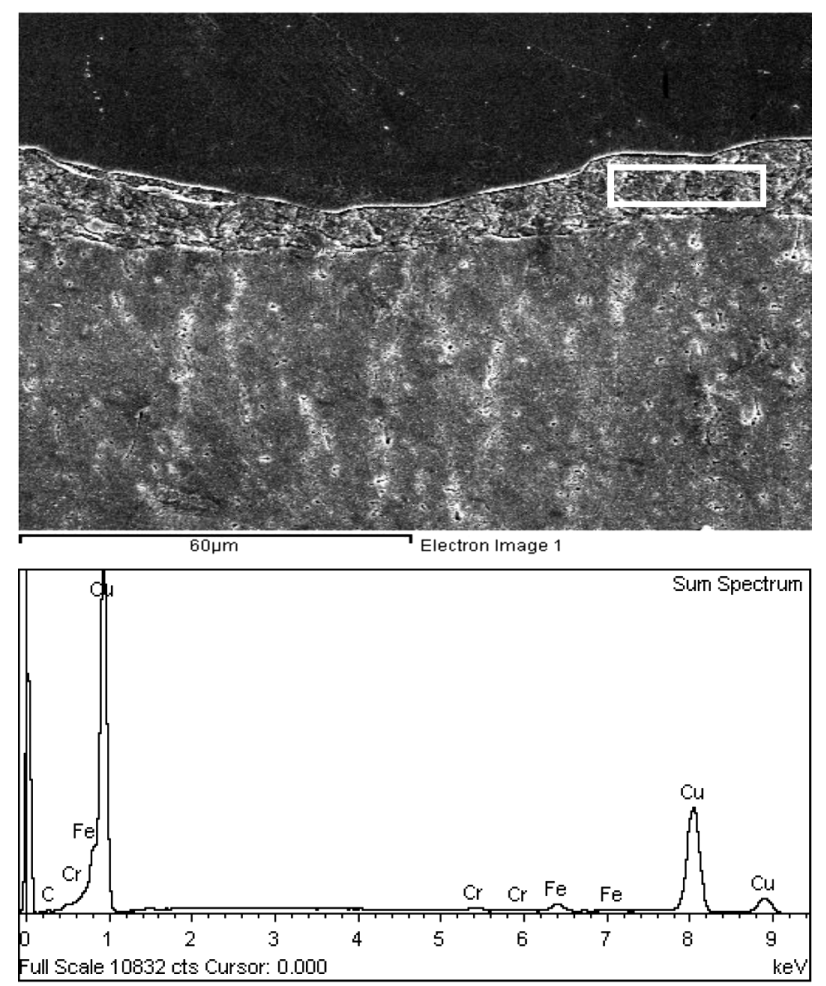

Figure 9: EDS analysis of the intermetallic-phase zone of a joint: a) SEM, b) EDS spectrum

Slika 9: EDS-analiza intermetalne faze na stiku: a) SEM, b) EDS spekter 


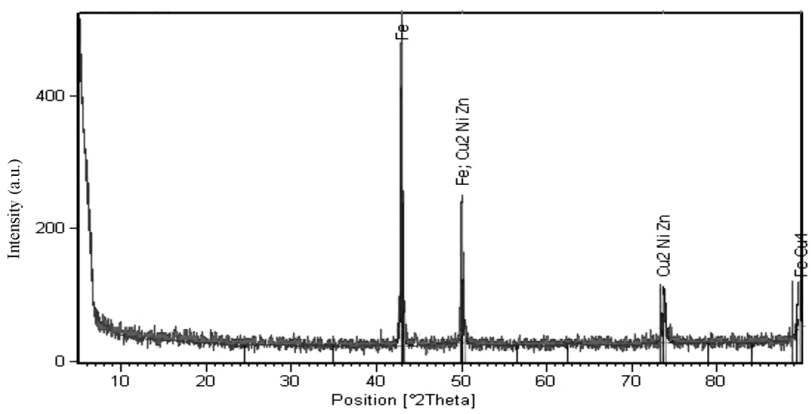

Figure 10: XRD results for the welding zone of a joint Slika 10: Rezultati rentgenske analize (XRD) v zvaru stika

Table 7: EDS analysis of the defined zone at the interface Tabela 7: EDS-analiza označenega področja na stiku

\begin{tabular}{|c|c|c|}
\hline Element & $(w / \%)$ & $(x / \%)$ \\
\hline $\mathrm{C}$ & 2.70 & 12.72 \\
\hline $\mathrm{Cr}$ & 0.98 & 1.07 \\
\hline $\mathrm{Fe}$ & 2.96 & 3.00 \\
\hline $\mathrm{Cu}$ & 93.36 & 83.21 \\
\hline Total & 100.00 & \\
\hline
\end{tabular}

than that of the steel side. There is no change in the grain size on the steel side. The presence of small particles on the copper side reveals hardening on this side. There are equiaxed $\alpha$ grains and $\mathrm{Cu}_{2} \mathrm{O}$ particles on the copper side. The interface elements of both materials diffused along the interface and some intermetallic phases were formed at the interface as reported in ${ }^{20,21}$.

The EDS analysis performed at a defined zone of the interface showed that the interface was formed of $2.70 \%$ C, $0.98 \% \mathrm{Cr}, 2.96 \% \mathrm{Fe}$ and $93.36 \% \mathrm{Cu}$ (Table 7). Thus, the presence of intermetallic phases at the interface is obvious. Copper-oxide films were broken into pieces due to an excessive deformation at the interface caused by the rotation (Figure 9). According to Figure 10, the X-ray diffraction results for friction-welded stainless steel-copper joints indicated that $\mathrm{FeCu}_{4}$ and

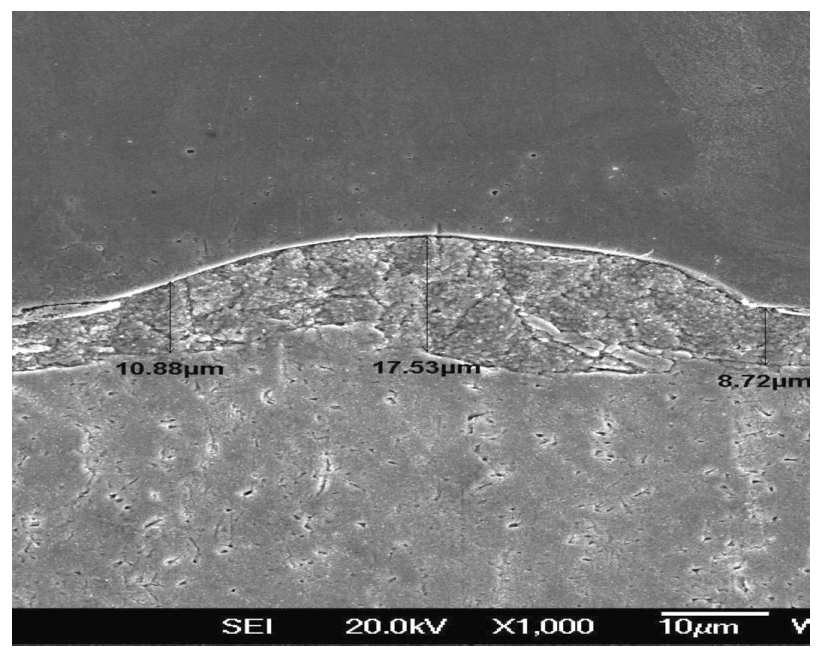

Figure 11: Thicknesses of the intermetallic phases at the interface Slika 11: Debelina intermetalnih faz na stiku

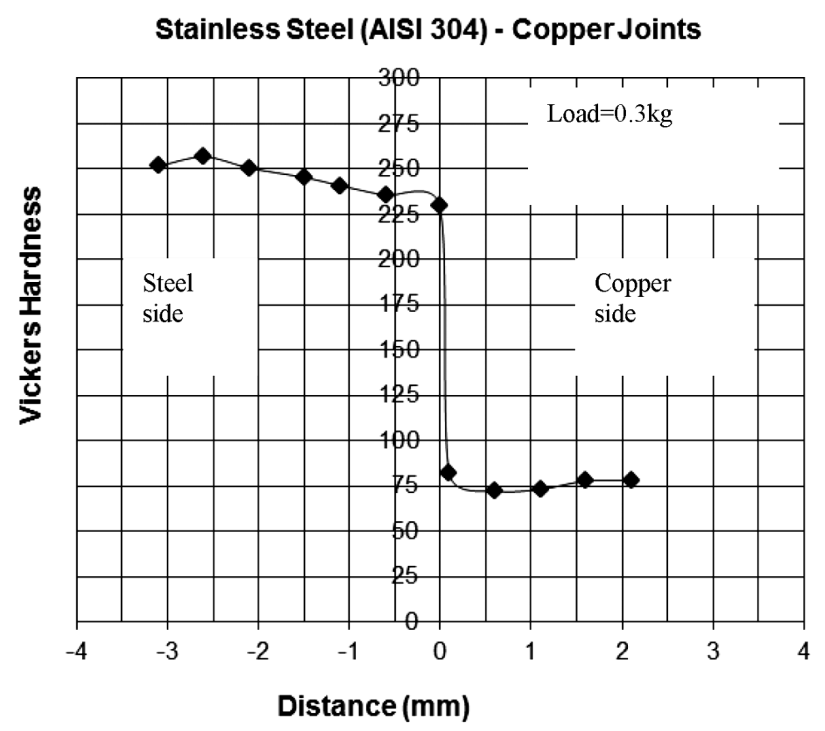

Figure 12: Microhardness variation across the joint Slika 12: Spreminjanje mikrotrdote preko spoja

$\mathrm{Cu}_{2} \mathrm{NiZn}$ intermetallics were formed in the welding zone. The thickness of the layer containing the intermetallic phases varied between $8.72 \mu \mathrm{m}$ and $17.53 \mu \mathrm{m}$ (Figure 11).

\subsection{Microhardness measurement}

The microhardness of a joint was measured across the weld region and the values were plotted as shown in Figure 12. The microhardness is maximum at the interface; this may be due to the formation of brittle intermetallics, and it is one of the reasons for a lower tensile strength of dissimilar joints.

\section{CONCLUSIONS}

Stainless-steel and copper parts were successfully friction joined in this work. The following important conclusions were obtained from this investigation:

- Empirical relationships were developed to predict the tensile strength of the friction-welded stainless-steel and copper parts incorporating process parameters at a $95 \%$ confidence level. The friction-welding parameters were optimized with the response-surface methodology to attain the maximum tensile strength.

- The maximum tensile strength of $223 \mathrm{MPa}$ was attained in the friction-welded joints under the following welding conditions: a friction pressure/ time relation of $8.82 \mathrm{MPa} / \mathrm{s}$, an upset pressure/time relation of $8 \mathrm{MPa} / \mathrm{s}$ and a rotational speed of $23.5 \mathrm{~s}^{-1}$.

- The friction pressure/friction time relation was found to have the greatest influence on the tensile strength of the joints, followed by the rotational speed.

- Various intermetallic phases such as $\mathrm{FeCu}_{4}$ and $\mathrm{Cu}_{2} \mathrm{NiZn}$ occurred at the interface. The formation of intermetallics at the interface is responsible for the 
higher hardness and lower tensile strength of the friction-welded stainless steel-copper joints.

- The intermetallic phases at the interface are also expected to play a role in the hardness variations.

\section{Acknowledgement}

The author would like to thank Trakya University/Edirne-Turkey, Hema Industry/Çerkezköy-Turkey and TUBITAK MRC/Gebze-Turkey for the help in the experimental part of the study.

\section{REFERENCES}

${ }^{1}$ V. I. Vill, Friction Welding of Metals, AWS, New York 1962

${ }^{2} \mathrm{~W}$. Kinley, Inertia welding: simple in principle and application, Welding and Metal Fabrication, (1979), 585-589

${ }^{3}$ N. I. Fomichev, The friction welding of new high speed tool steels to structural steels, Weld. Prod., (1980), 35-38

${ }^{4}$ C. R. G. Ellis, Friction Welding; some recent applications of friction welding, Welding and Metal Fabrication, (1977), 207-213

${ }^{5}$ K. P. Imshennik, Heating in friction welding, Weld. Prod., (1973), 76-79

${ }^{6}$ T. Rich, R. Roberts, Thermal analysis for basic friction welding, Met. Const. and British Weld. J., (1971), 93-98

${ }^{7}$ A. Sluzalec, International Journal of Mechanical Sciences, 32 (1990) 6, 467-478, doi:10.1016/0020-7403(90)90153-A

${ }^{8}$ M. Sahin, H. E. Akata, Journal of Materials Processing Technology, 142 (2003) 1, 239-246, doi:10.1016/S0924-0136(03)00589-2

${ }^{9}$ M. Sahin, H. E. Akata, Industrial Lubrication \& Tribology, 56 (2004) 2, 122-129, doi:10.1108/00368790410524074

${ }^{10}$ M. Sahin, Assembly Automation, 25 (2005) 2, 140-145, doi:10.1108/01445150510590505

${ }^{11}$ M. Sahin, Materials and Design, 28 (2007) 7, 2244-2250, doi:10.1016/j.matdes.2006.05.031

${ }^{12}$ A. W. E. Nentwig, Friction welding of cross section of different sizes, Schweissen und Schneiden/Welding \& Cutting, 48 (1996) 12, 236-237
${ }^{13}$ B. S. Yılbaş, A. Z. Şahin, N. Kahraman, A. Z. Al-Garni, Journal of Materials Processing Technology, 49 (1995) 3-4, 431-443, doi:10.1016/0924-0136(94)01349-6

${ }^{14}$ A. Z. Şahin, B. S. Yılbaş, M. Ahmed, J. Nickel, Journal of Materials Processing Technology, 82 (1998) 1-3, 127-136, doi:10.1016/S0924-0136(98)00032-6

${ }^{15}$ W. B. Lee, S. B. Jung, Zeitschrift für Metallkunde, 94 (1993) 12, 1300-1306, doi:10.3139/146.031300

${ }^{16}$ S. A. Fabritsiev, A. S. Pokrovsky, M. Nakamichi et al., Journal of Nuclear Materials, 258 (1998) 2, 2030-2035, doi:10.1016/S00223115(98)00126-3

${ }^{17}$ L. Fu, S. G. Du, Journal of Materials Science, 41 (2006) 13, 4137-4142, doi:10.1007/s10853-006-6224-5

${ }^{18}$ K. Jayabharath, M. Ashfaq, P. Venugopal et al., Materials Science and Engineering A: Structural Materials: Properties, Microstructure and Processing, 454-455 (2007), 114-123, doi:10.1016/j.msea.2006. 11.026

${ }^{19}$ M. Maalekian, Science and Technology of Welding \& Joining, 12 (2007) 8, 738-759, doi:10.1179/174329307X249333

${ }^{20}$ M. Sahin, Industrial Lubrication and Tribology, 61 (2009) 6, 319-324, doi:10.1108/00368790910988435

${ }^{21}$ M. Sahin, E. Çil, C. Misirli, Journal of Materials Engineering \& Performance, 22 (2013) 3, 840-847, doi:10.1007/s11665-012-0310-4

${ }^{22}$ K. G. K. Murti, S. Sundaresan, Parameter optimisation in friction welding dissimilar materials, Metal Construction, 15 (1983) 6, 331-335

${ }^{23}$ R. Karthikeyan, V. Balasubramanian, International Journal of Advanced Manufacturing Technology, 51 (2010) 1-4, 173-183, doi:10.1007/s00170-010-2618-2

${ }^{24}$ S. T. Selvamani, K. Palanikumar, Measurement: Journal of the International Measurement Confederation, 53 (2014), 10-21, doi:10.1016/j.measurement.2014.03.008

${ }^{25}$ C. W. Wegst, Stahlschlüssel, Verlag Stahlschlüssel Wegst GmbH, Marbach 1995

${ }^{26}$ G. E. P. Box, W. H. Hunter, J. S. Hunter, Statistics for experiment, John Wiley Publications, New York 1978

${ }^{27}$ A. I. Khuri, J. Cornell, Response Surfaces, Design and Analysis, Marcel Dekker, New York 1996 